\title{
Plasma Kisspeptin Levels in Girls with Premature Thelarche
}

\author{
Ayşehan Akıncı1, Dilek Çetin2, Nevin Ilhan2 \\ ${ }^{1}$ Inönü University, Turgut Özal Medical Center, Department of Paediatric Endocrinology, Malatya, Turkey \\ ${ }^{2}$ Fırat University Faculty of Medical, Department of Biochemistry, Elazığ, Turkey
}

\begin{abstract}
Objective: Premature thelarche (PT) is defined as isolated breast development without secondary sex characteristics in girls below the age of eight. We aimed to determine whether the level of kisspeptin, which plays a role in the release of gonadotropins, is associated with PT.

Methods: The patient group included children with PT aged 3-8 years $(n=20)$ and the control group included healthy children in the same age range $(\mathrm{n}=20)$. Height standard deviation scores (HSDSs), bone maturation and growth velocity were evaluated in the two groups. Basal follicle-stimulating hormone $($ FSH), luteinizing hormone (LH), estradiol (E2), prolactin (PRL), and sex hormone-binding globulin (SHBG) levels were also measured in the two groups by immunochemiluminometric assay (ICMA). A gonadotropin-releasing hormone (GnRH) test was also conducted in the patient group and the peak levels of FSH and LH were determined. Kisspeptin levels were measured using enzyme immunoassay (EIA).

Results: No differences were found between the groups in terms of age, HSDS, annual growth rate and bone age. While the plasma basal FSH, LH and E2 levels in the patient and control groups did not show statistically significant differences, PRL levels were higher in the patient group $(p<0.05)$. Peak LH response to $\mathrm{GnRH}$ test was at the prepubertal level $(<5 \mathrm{ng} / \mathrm{mL})$ in patients with PT. In the patient group, kisspeptin levels were significantly higher compared to the levels in the control group $(2.96 \pm 1.21 \mathrm{ng} / \mathrm{dL}$ vs. $1.19 \pm 0.41 \mathrm{ng} / \mathrm{dL} ; \mathrm{p}<0.05)$, and kisspeptin levels showed a significant correlation with PRL, FSH, LH, and E2 levels ( $p<0.05)$.

Conclusions: In this study, plasma kisspeptin levels were found to be higher in patients with PT and to show a positive correlation with increased PRL levels. Kisspeptin is one of the neuropeptides that plays a role in the onset of puberty. Our results support the hypothesis that PT may result from the temporary activation of central stimulants.

Key words: Kisspeptin, premature thelarche
\end{abstract}

Conflict of interest: None declared

Received: 23.01.2012

Accepted: 01.03 .2012

\section{Introduction}

Breast enlargement or thelarche is the first sign that indicates the onset of physiological puberty in girls. On the other hand, premature thelarche (PT) is defined as isolated breast development without other features of puberty (e.g. accelerated growth velocity, advanced bone maturation, axillary and pubic hair development) in girls below the age of 8 years. Although the onset of PT shows a peak around the first two years of life, it may also occur during any period between the ages of 2 and 8 years $(1,2)$. PT may be a mild benign form of hypothalamic-pituitary-gonadal (HPG) axis activation and occasionally, may develop as a result of an accelerated maturation of HPG axis activation. It may show rapid progression to precocious puberty, with an incidence of approximately $14 \%$ (3). The pathophysiology of PT remains to be elucidated. Various mechanisms are responsible for PT, such as increased sensitivity of breast tissue to estrogen $(4,5)$, temporary estrogen release from ovarian follicular cysts (4), increased estrogen production from adrenal precursors such as dehydroepiandrosterone sulphate (6), exposure to exogenous estrogens (7), increased aromatase enzyme activity (8), relative increase of estrogen related to increased level of sex hormonebinding globulin (SHBG) (9), and temporary activation of HPG axis (10). The main hormones that contribute to breast development in puberty include estradiol (E2), progesterone, prolactin (PRL), growth hormone, and several growth factors such as insulin-like growth factor-1 and epidermal growth factor (11). The mechanisms activating these hormones in PT, which act without inducing other signs of puberty, has not been fully understood.

\section{Address for Correspondence}

Ayşehan Akıncı MD, Inönü University, Turgut Özal Medical Center, Department of Paediatric Endocrinology Unit, Malatya, Turkey

Phone: +90 4223410660 E-mail: aakinci@inonu.edu.tr

(c) Journal of Clinical Research in Pediatric Endocrinology, Published by Galenos Publishing. 
Kisspeptin is a neuropeptide, encoded by Kiss-1 gene. Kisspeptin and the $\mathrm{G}$ protein-coupled receptor 54 system (GPR54/Kiss1R) are recognized as essential regulators of puberty onset and of gonadotropin secretion (12) . It has been found that the kisspeptin/GPR54 complex stimulates HPG axis activation and regulates energy metabolism $(13,14,15)$. Recent studies have shown that kisspeptin levels are significantly higher in girls with central precocious puberty than in prepubertal girls, and this finding is positively correlated with peak levels of folliclestimulating hormone (FSH) and luteinizing hormone ( $\mathrm{LH}$ ) after gonadotropin-releasing hormone $(\mathrm{GnRH})$ stimulation $(16,17)$. For these reasons, it is speculated that kisspeptin plays an important contributive role in the onset of puberty. In this study, we aimed to investigate the role of central stimulants in the onset of PT by measuring plasma kisspeptin levels in patients with PT.

\section{Methods}

The patient group included 20 girls aged between 3-7 years who presented to the outpatient clinic of our pediatric endocrinology unit with a complaint of unusual breast development. The control group consisted of 20 age-matched healthy girls who were admitted to the hospital for routine health control and who were not on any medication. The study was approved by the institutional ethics review board and written informed consent was obtained from all the families. Information was obtained on age at onset of PT, progression rate of the symptoms, annual growth rate, medications used, and maternal menarche age. Height standard deviation score (HSDS) and body mass index SDS (BMISDS) were calculated in the patients and controls according to Turkish reference values (18). Bone age (BA) of the patients and controls were assessed by the Tanner-Whitehouse method. Breast development was evaluated according to the Tanner staging (19). Uterine and ovarian sonographic (USG) examinations were performed and interpreted by the same investigator using a USG apparatus (Acuson Antares, Siemens 2010) with a 1-4 mHz transducer. The USG scans were performed transabdominally when the patients/controls had a full bladder, obtained by voluntary urine retention and oral administration of fluids. On pelvic USG, ovarian and uterine volumes [longitudinal diameter (A), largest transverse diameter (B), largest anterior-posterior diameter (C)] were calculated using the ellipsoid formula ( $\mathrm{AxB} \times \mathrm{C} \times 0.52)$. Endometrial thickness and presence/absence of follicular cysts were also investigated. On USG evaluation, a uterine volume of $<3 \mathrm{~cm}^{3}$, an ovarian volume of $<1 \mathrm{~cm}^{3}$ and an endometrial thickness of $<1 \mathrm{~mm}$ were considered as prepubertal $(20,21,22)$. In the patient and control groups, basal free thyroxine (fT4), thyroid-stimulating hormone (TSH), LH, FSH, SHBG, E2 and PRL levels were measured by immunochemiluminometric assay (ICMA) on an Immulite 2000 analyzer (Siemens; catalog numbers:
FSH:L2KFS2， LH:L2KLH2， E2:L2KE22， PRL:L2KPR2, SHBG:L2KSH2). GnRH stimulation test was performed in all patients with $\mathrm{PT}$.

Subjects with basal LH values of $<0.3 \mathrm{mlU} / \mathrm{mL}$ (ICMA), peak $\mathrm{LH}$ levels of $<5 \mathrm{mlU} / \mathrm{mL}$ during the $\mathrm{GnRH}$ test, with $\mathrm{BA} /$ chronological age ratios of $<1$, a normal annual height increase according to age and a regression or a cessation of breast development at the end of 1-year monitoring, and who showed no other signs of puberty such as axillary or pubic hair development were considered as having PT $(23,24,25,26,27,28)$. These patients were evaluated by measurement of FSH, LH, E2, and PRL levels and by pelvic USG every 3 months for a period of 1.5 years. During this follow-up period, no significant changes were observed in the hormonal levels or pelvic USG findings, and none of the patients developed other signs of precocious puberty.

Measurement of kisspeptin: For measurement of kisspeptin level, blood samples were drawn from the patient and control groups into tubes containing EDTA and aprotinine, a protease inhibitor. The tubes were immediately centrifuged at $1.600 \mathrm{rpm}$ at a temperature of $4^{\circ} \mathrm{C}$ for 15 minutes, and the samples were stored at $-80^{\circ} \mathrm{C}$ until time of measurement. Before initiating the measurement, the peptides were extracted from the plasma. For measurements, the following steps were followed using the buffers and columns required along with the kit: The first step was to acidify the plasma using an equal amount of buffer A (Catalogue No: RKBA-1). After being well-mixed, the sample was centrifuged at 6 000-17 $000 \mathrm{rpm}$ at a temperature of $4^{\circ} \mathrm{C}$ for 20 minutes. Then, the SEP-COLUMN that contains 200 mg C18 (Catalogue no: RKSEPCOL-1) was equilibrated by washing with $1 \mathrm{~mL}$ buffer $B$ (Catalogue no: RKBB-1) once. Then, the sample was washed twice with $3 \mathrm{~mL}$ buffer $A$ and the resulting solution was separated. The peptides were then eluted with $3 \mathrm{~mL}$ buffer $B$ and the eluents were collected into polystyrene tubes.

Kisspeptin was measured using a commercial enzyme immunoassay (EIA) kit called Kiss-1 [112-121] Amide/ Kisspeptin-10 / Metastin (45-54) Amide (Human) (Cat\# EK048-56), (Phoenix Pharmaceuticals, Inc., Burlingame, California, USA) and according to the directions provided in the kit content. At the end of the study, ELISA plate (TRITURUS, Barcelona, Spain) was read at $450 \mathrm{~nm}$, and the results were calculated according to standards $(\mathrm{ng} / \mathrm{mL})$.

Statistical Methods: Statistical analyses were performed using SPSS for Windows, version 11.0. All the data were reported as means $\pm S D$. Normality for continued variables in the groups was determined by Shapiro-Wilk test. The variables showed normal distribution ( $>0.05$ ), so the unpaired t-test was used for comparisons of the groups for variables and the Pearson's correlation test - for correlations between the variables. A p-value of $<0.05$ was considered significant. 


\section{Results}

Clinical and ultrasound findings of 20 girls diagnosed with PT and of 20 healthy girls are given in Table 1. No statistically significant difference was found between patient and control groups in terms of auxological characteristics lage, HSDS, BMISDS, BA) ( $p>0.05)$.

In the PT group, all patients were evaluated as Tanner stage2 breast development, except for one girl who showed Tanner stage-3 breast development. At presentation, breast development was bilateral in $60 \%$ and unilateral in $40 \%$ of the patient group. Of the patients with unilateral breast development, $62.5 \%$ had left and $37.5 \%$ had right breast development. No statistically significant differences were found between the patient and control groups in terms of ovarian and uterine volumes ( $p>0.05$ ) (Table 1). The basal E2, PRL, SHBG, LH, FSH and kisspeptin levels in both PT patients and controls as well as the peak FSH and $\mathrm{LH}$ response values to $\mathrm{GnRH}$ stimulation in the patient group are presented in Table 2. While the patient and control groups did not statistically significantly differ in terms of basal FSH, LH, SHBG, and E2 levels ( $>0.05$ ), basal PRL levels were higher in the patient group $(p<0.05)$ (Table 2). The mean peak values of $\mathrm{LH}$ and $\mathrm{FSH}$ during $\mathrm{GnRH}$ test in the patient group are shown in Table 2.

Higher FSH peak values after $\mathrm{GnRH}$ stimulation were consistent with the diagnosis of PT. Peak LH levels of the patients were within the prepubertal range. Kisspeptin levels were significantly higher in the patient group than in the control group ( $p<0.05$ ) (Table 2 ).

In the patient group, a statistically significant positive correlation was found between kisspeptin level and basal E2, $\mathrm{LH}, \mathrm{FSH}, \mathrm{PRL}$ levels, and $\mathrm{GnRH}$-stimulated $\mathrm{LH}$ peak values $(r=0.45, p<0.05 ; \quad r=0.49, p<0.05 ; \quad r=0.42, p<0.05 ; \quad r=0.45$, $p<0.05$; and $r=0.49, p<0.05$, respectively). There was no

Table 1. Clinical and USG findings in patients and controls

\begin{tabular}{lccc}
\hline & $\begin{array}{c}\text { Patient group } \\
(\mathbf{n}=\mathbf{2 0}) \\
\text { Mean } \pm \mathbf{S D}\end{array}$ & $\begin{array}{c}\text { Control group } \\
(\mathbf{n = 2 0 )}\end{array}$ \\
Mean $\pm \mathbf{S D}$ & $\mathbf{p}$ \\
\hline Age (years) & $6.15 \pm 1.28$ & $6.10 \pm 1.42$ & 0.146 \\
HSDS & $1.24 \pm 0.84$ & $1.08 \pm 0.88$ & 0.157 \\
BMI SDS & $1.25 \pm 0.4$ & $1.16 \pm 0.9$ & 0.23 \\
Bone age (years) & $6.70 \pm 1.43$ & $6.62 \pm 0.2$ & 0.241 \\
Right ovarian volume $\left(\mathrm{cm}^{3}\right)$ & $0.88 \pm 0.03$ & $0.95 \pm 0.04$ & 0.072 \\
Left ovarian volume $\left(\mathrm{cm}^{3}\right)$ & $0.96 \pm 0.02$ & $0.94 \pm 0.02$ & 0.084 \\
Uterine volume $\left(\mathrm{cm}^{3}\right)$ & $1.82 \pm 0.71$ & $1.7 \pm 0.63$ & 0.349 \\
\hline p<0.05=significant & \multicolumn{3}{|}{} \\
HSDS: height standard deviation score, BMI: body mass index, USG: ultrasonography
\end{tabular}

significant correlation between kisspeptin level and E2, FSH, $\mathrm{LH}$ and $\mathrm{PRL}$ levels in the control group. We did not find any correlations between kisspeptin levels and BMISDS of patients and controls. All the cases with PT were followed up for a mean period of $15.2 \pm 1.57$ months. Breast findings resolved within $6 \pm 1.45$ months in 3 cases with unilateral breast enlargement; the others did not show any progression. The breast findings resolved in five cases with bilateral breast enlargement within $10 \pm 1.62$ months; in the others, breast growth regressed but did not disappear. When the patients with PT were divided with respect to the resolution of breast tissue, there were no significant differences between kisspeptin levels of both groups. In the PT group, no signs of early puberty were seen at follow-up.

\section{Discussion}

In our study, anthropometric measurements of the PT group were within normal limits for age, and the mean values ofanthropometric values in the PT group were not different from those in the control group. Moreover, in the PT patients, at the and of a follow-up of nearly 1.5 years, no findings suggesting early puberty were observed based on physical examination and pelvic USG evaluation. These findings confirmed a diagnosis of PT in the patient group.

The etiology of PT remains poorly understood. Various hypotheses have been proposed, and PT most likely arises from any one or a combination of these mechanisms. Hypothyroidism

Table 2. Hormone levels in patients and controls

\begin{tabular}{|c|c|c|c|}
\hline & $\begin{array}{l}\text { Patient group } \\
(n=20) \\
\text { Mean } \pm S D\end{array}$ & $\begin{array}{l}\text { Control group } \\
\qquad(n=20) \\
\text { Mean } \pm \text { SD }\end{array}$ & $\mathbf{p}$ \\
\hline fT4 ( ng/dL) & $1.25 \pm 0.8$ & $1.38 \pm 0.5$ & 0.340 \\
\hline $\mathrm{TSH}(\mathrm{mlU} / \mathrm{mL})$ & $2.53 \pm 0.9$ & $2.96 \pm 0.4$ & 0.130 \\
\hline $\mathrm{E} 2(\mathrm{pg} / \mathrm{mL})$ & $11.63 \pm 1.57$ & $10.40 \pm 1.25$ & 0.897 \\
\hline PRL (ng/mL) & $12.01 \pm 7.98$ & $8.00 \pm 4.65$ & 0.033 \\
\hline $\mathrm{LH}(\mathrm{mlU} / \mathrm{mL})$ & $0.14 \pm 0.15$ & $0.11 \pm 0.03$ & 0.174 \\
\hline $\mathrm{FSH}(\mathrm{mIU} / \mathrm{mL})$ & $2.31 \pm 1.12$ & $1.78 \pm 0.72$ & 0.092 \\
\hline SHBG (nmol/L) & $70 \pm 30.52$ & $80 \pm 19.88$ & 0.194 \\
\hline Kisspeptin (ng/mL) & $2.96 \pm 1.21$ & $1.19 \pm 0.41$ & 0.001 \\
\hline $\begin{array}{l}\text { Peak of } \mathrm{LH} \text { with } \mathrm{GnRH} \\
\text { stimulation }(\mathrm{mlU} / \mathrm{mL})\end{array}$ & $3.05 \pm 1.06$ & & \\
\hline $\begin{array}{l}\text { Peak of FSH with GnRH } \\
\text { stimulation }(\mathrm{mlU} / \mathrm{mL})\end{array}$ & $14.90 \pm 1.37$ & & \\
\hline
\end{tabular}


typically causes pubertal delay but may also induce a syndrome of pseudoprecocity manifested as breast enlargement and vaginal bleeding in girls (29). In our patients, fT4 and TSH levels were within normal limits. Oral ingestion of estrogen-containing foods or medications can cause PT (7).

E2 levels in girls slowly rise from infancy through childhood until puberty, but some girls with PT may have an increased sensitivity of breast tissue to small amounts of estrogens. Some girls may have a prolonged minipuberty with delayed inactivation of the HPG axis, leading to increased estradiol levels and, consequently, to PT $(30,31)$. Increased peripheral aromatase activity may be another source of estrogens. Obese or overweight girls may have increased peripheral aromatase activity and breast development (8). In our study, BMl values were within normal limits and were comparable in the patient and control groups. Basal gonadotropin levels are considered a leading sign in deciding whether isolated breast development is accompanied by the activation of HPG axis, in other words, whether "central puberty" has begun (32). Some studies have reported LH secretion during sleep in children with PT to be similar to that seen in puberty (33), whereas others have not confirmed these findings (34). In prepubertal girls who show the initial symptoms of puberty ( breast enlargement), LH values of $>0.3 \mathrm{mlU} / \mathrm{mL}$ (by ICMA) and $\mathrm{LH}$ peak values with $\mathrm{GnRH}$ stimulation of $>5 \mathrm{mlU} / \mathrm{mL}$ (by ICMA) indicate central precocious puberty $(24,25)$. In our study, the basal and peak LH values in our patients were $<0.3 \mathrm{mlU} / \mathrm{mL}$ and $<5 \mathrm{mlU} / \mathrm{mL}$, respectively, and these values were not different from those in the control group. PT is typically associated with increased FSH and increased inhibin $\mathrm{B}$ secretion. Breast enlargement may be a consequence of fluctuations in the female childhood HPG axis activation, with temporary FSH-stimulated increases in ovarian steroids $(5,10)$. In our study, FSH predominance was observed in $\mathrm{GnRH}$ stimulation test.

Although the mechanisms used to control or initiate episodic release of hypothalamic $\mathrm{GnRH}$ remain incompletely understood, some neuropeptides like GABA, dopamine and serotonin are known to play an inhibitory role, while others, such as kisspeptin, noradrenaline and glutamate, stimulate the gonadotropin release $(35,36)$. Recently discovered kisspeptin is a neuropeptide encoded by Kiss- 1 gene (1q32). Kisspeptin, which is synthesized in the central nervous system, stimulates gonadotropin release by binding to GPR54, located on GnRH neurons in the hypothalamus $(12,13,14,15)$. This protein, GPR54, appears to be necessary in mammals for the pulsatile $\mathrm{FSH}$ and $\mathrm{LH}$ release at the onset of puberty. In men, it has been shown that inactivating mutation in GPR54 resulted in decreased $\mathrm{GnRH}$ secretion and hypogonadism (37). In patients with GPR54 mutations, peak LH and FSH levels were found to be decreased, while these values were increasing with $\mathrm{GnRH}$ stimulation. These findings support the view that kisspeptin/GPR54 signal system is important in pubertal timing. Otherwise, in some girls, an increased expression of the Kiss-1 gene leading to increased kisspeptin levels may be the cause of central precocious puberty, or could be the result of increased activation of the GPR54 signal system. Recent studies show that kisspeptin plays an important role in the onset of puberty (9) because the girls diagnosed with precocious puberty had higher plasma levels of kisspeptin in earlier studies (38). Animal studies have shown that peripheral or cerebroventricular kisspeptin injections increase the peak values of $\mathrm{LH}$ and $\mathrm{FSH}$ $(39,40)$. In a recently performed study, kisspeptin- 54 was given to male volunteers and an increase in their LH, FSH and testosterone levels was observed (13). These findings show that kisspeptin/GPR54 signal system plays a crucial role in triggering $\mathrm{FH}$ and $\mathrm{FSH}$ secretions. In PT patients, FSH predominance suggests the role of central stimulants in the occurrence of PT. In this research also, PRL levels were higher in PT patients than in the control group, and they were significantly correlated with kisspeptin levels. Experimental studies have shown that intraventricular injection of kisspeptin-10 inhibits the dopaminergic neurons and increases PRL levels $(41,42)$. In our study, the significantly higher plasma levels of kisspeptin and PRL as well as the significant positive correlation between plasma levels of kisspeptin and basal hormone levels (FSH, LH, E2, PRL) in the girls with PT suggest that PT may be directly related to a premature increase of kisspeptin leading to premature activation of the HPG axis or that this relationship may be an indirect one, via a kisspeptin-induced increase in PRL. Studies on kisspeptin levels in childhood are limited. Further studies are warranted to achieve a better understanding about the role of kisspeptin in the occurrence of PT or to document the usefulness of kisspeptin as a marker in the diagnosis of PT.

\section{References}

1. Diamantopoulos S, Bao Y. Gynecomastia and premature thelarche. A guide for general practitioners. Pediatr Rev 2007:28:57-68

2. Muir A. Precocious puberty. Pediatr Rev 2006;27:373-381

3. Pasquino AM, Pucarelli I, Passeri F, Segni M, Mancini MA, Municchi G. Progression of premature thelarche to central precocious puberty. J Pediatr 1995;126:11-14.

4. Sizonenko PC. Preadolescent and adolescent endocrinology: physiology and physiopathology. Hormonal changes during abnormal pubertal development. Am J Dis Child 1978;132:797805.

5. Ilicki A, Prager Lewin R, Kauli R, Kaufman H, Schachter A, Laron $Z$. Premature thelarche: natural history and sex hormone secretion in 68 girls. Acta Paediatr Scand1984;73:756-762.

6. Dumic M, Tajic M, Mardesic D, Kalafatic Z. Premature thelarche: a possible adrenal disorder. Arch Dis Child 1982;57:200-203.

7. Saenz de Rodriguez CA, Bongiovanni AM, Conde de Barrego L. An epidemic of precocious development in Puerto Rican children. J Pediatr 1985;107:393-396.

8. Stratakis CA, Vottero A, Brodie A, Kirschner LS, DeAtkine D, Lu Q, Yue W, Mitsiades CS, Flor AW, Chrousos GP. The aromatase excess syndrome is associated with feminization of both sexes and autosomal dominant transmission of aberrant P450 aromatase gene transcription. J Clin Endocrinol Metab 1998:83:1348-1357.

9. Belgorosky A, Chaler E, Rivarola MA. High serum sex hormone-binding globulin (SHBG) in premature thelarche. Clin Endocrinol (Oxf) 1992;37:203-206. 
10. Crofton PM, Evans NE, Wardhaugh B, Groome NP, Kelnar CJ. Evidence for increased ovarian follicular activity in girls with premature thelarche. Clin Endocrinol (Oxf) 2005;62:205-209.

11. Kleinberg DL, Barcellos-Hoff MH. The pivotal role of insulin-like growth factor-1 in normal mammary development. Endocrinol Metab Clin North Am 2011:40:461-471.

12. Garcia-Galino D, Pinilla L, Tena-Sempere M. Sex steroids and the control of the Kiss1 system: Developmental roles and major regulatory actions. J Neuroendocrinol 2011;24:22-33.

13. Dhillo WS, Chaudhri OB, Patterson M, Thompson EL, Murphy KG, Badman MK, McGowan BM, Amber V, Patel S, Ghatei MA Bloom SR. Kisspeptin-54 stimulates the hypothalamic-pituitarygonadal axis in human males. J Clin Endocrinol Metab 2005;90:6609-6615.

14. Seminara SB. Metastin and its G protein-coupled receptor, GPR54: critical pathway modulating $\mathrm{GnRH}$ secretion. Front Neuroendocrinol 2005;26:131-138.

15. Kaiser UB, Kuohung W. Kiss- 1 and GPR54 as new players in gonadotropin regulation and puberty. Endocrine 2005;26:277-284.

16. de Vries L, Shtaif B, Phillip M, Gat-Yablonski G. Kisspeptin serum levels in girls with central precocious puberty. Clin Endocrinol (Oxf) 2009:71:524-528.

17. Rhie YJ, Lee KH, Eun SH, Choi BM, Chae HW, Kwon AR, Lee WJ, Kim JH, Kim HS. Serum kisspeptin levels in Korean girls with central precocious puberty. J Korean Med Sci 2011;26:927-931.

18. Bundak R, Furman A, Gunoz H, Darendeliler F, Bas F, Neyzi O. Body mass index references in Turkish Children. Acta Paediatr 2006:95:194-198.

19. Marshall WA, Tanner JM. Variations in the pattern of pubertal changes in girls. Arch Dis Child 1969:44:291-303.

20. Haber HP, Wollmann HA, Ranke MB. Pelvic ultrasonography: early differentiation between isolated premature thelarche and central precocious puberty. Eur J Pediatr 1995;154:182-186.

21. Battaglia C, Mancini F, Regnani G, Persico N, lughetti L, De Aloysio D. Pelvic ultrasound and color Doppler findings in different isosexual precocities. Ultrasound Obstet Gynecol 2003:22:277-283

22. Herter LD, Golendziner E, Flores JA, Moretto M, Di Domenico K, Becker E Jr, Spritzer PM. Ovarian and uterine findings in pelvic sonography: comparison between prepubertal girls, girls with isolated thelarche, and girls with central precocious puberty. $J$ Ultrasound Med 2002:21:1237-1246.

23. Imel EA, Bethin KE. Etiology of gonadotropin-dependent precocious puberty.In: When puberty is precocious. Scientific and clinical aspect.Eds, Pescovitz $\mathrm{O}$ and Walvoord EC.2007, humana press,New Jersey,pp:331-334.

24. Dattani MT. Tests in pediatrics endocrinology and normal values, Clinical Pediatrics Endocrinology. Fourth Ed. Ed by BrookCGD. Hindmarsh PC. London. Blackwell Scie. 2001,pp 467-95

25. Cavallo A, Richards GE, Busey S, Michaels E. A simplified gonadotropin-releasing hormone stimulating test for precious puberty. Clin Endocrinol 1995:42:641-646.

26. Apter D, Butzow TL, Laughlin GA, Yen SS. Gonadotropinreleasing hormone pulse generator activity during pubertal transition in girls: pulsatile and diurnal patterns of circulating gonadotropins. J Clin Endocrinol Metab 1993;76:940-949.

27. Wu FC, Butler GE, Kelnar CJ, Huhtaniemi I, Veldhuis JD. Ontogeny of pulsatile gonadotropin-releasing hormone secretion from midchildhood, through puberty, to adulthood in the human male: a study using deconvolution analysis and an ultrasensitive immunofluometric assay. J Clin Endocrinol Metab 1996:81:1798-1805.
28. Bourguignon JP, Rosenfield RL. Precocious breast development in a girl In: Algorithms of pediatric endocrinology (Hochberg Z ed.) Karger 2007; pp.14-15.

29. Foley TP Jr. Hypothyroidism. Pediatr Rev 2004;25:95-100.

30. Jenner MR, Kelch RP, Kaplan SL, Grümbach MM. Hormonal changes in puberty. IV. Plasma estradiol, LH, and FSH in prepubertal children, pubertal females, and in precocious puberty, premature thelarche, hypogonadism, and in a child with feminizing ovarian tumor. J Clin Endocrinol Metab 1972;34:521-530.

31. Klein KO, Baron J, Colli MJ, McDonnell DP, Cutler GB Jr. Estrogen levels in childhood determined by an ultrasensitive recombinant cell bioassay. J Clin Invest 1994;94:2475-2480.

32. Aritaki S, Takagi A, Someya H, Jun L. A comparison of patients with premature thelarche and idiopathic true precocious puberty in the initial stage of illness. Acta Paediatr Jpn 1997;39:21-27.

33. Beck W, Stubbe P. Pulsatile secretion of luteinizing hormone and sleep-related gonadotropin rhythms in girls with premature thelarche. Eur J Pediatr 1984;141:168-170.

34. Pescovitz OH, Hench KD, Barnes KM, Loriaux DL, Cutler GB Jr. Premature thelarche and central precocious puberty: the relationship between clinical presentation and the gonadotropin response to luteinizing hormone-releasing hormone. J Clin Endocrinol Metab 1988:67:474-479.

35. Lee PA, Houk CP. Puberty and its disorders. Ed: Liftshitz F, Pediatric Endocrinology., Informa Healthcare Inc, New York, USA, 2000:274-290.

36. Ojeda SR, Lomniczi A, Mastronardi C, Heger S, Roth C, Parent AS, Matagne $V$, Mungenast AE. Minireview: the neuroendocrine regulation of puberty: is the time ripe for a systems biology approach? Endocrinolgy 2006;147:11661174.

37. Messager S, Chatzidaki EE, Ma D, Hendrick AG, Zahn D, Dixon J, Thresher RR, Malinge I, Lomet D, Carlton MB, Colledge WH, Caraty A, Aparicio SA. Kisspeptin directly stimulates gonadotropin-releasing hormone release via G-protein coupled receptor 54. Proc Natl Acad Sci USA 2005:102:1761-1766.

38. de Vries L, Shtaif B, Philip M, Gat-Yablonski G. Kisspeptin serum levels in girls with central precocious puberty. Clin Endocrinol (Oxf) 2009;71:524-528.

39. Ezzat AA, Saito H, Sawada T, Yaegashi T, Goto Y, Nakajima Y, Jin J, Yamashita T, Sawai K, Hahizume T. The role sexual steroid hormones in the direct stimulation by kisspeptin- 10 of the secretin of luteinizing hormone, follicle stimulating hormone and prolactin from bovine anterior pituitary cells. Anim Reprod Sci 2010;121:267-272.

40. Kokay IC, Petersen SL, Grattan DR. Identification of prolactin-sensitive GABA and kisspeptin in regions of the rat hypothalamus involved in the control of fertility. Endocrinology 2011;152:526-535.

41. Kadokawa H, Suzuki S, Hashizume T. Kisspeptin-10 stimulates the secrection of growth hormone and prolactin directly from cultured bovine anterior pituitary cells. Anim Reprod Sci 2008;105:404-408.

42. Szawka RE, Ribeiro AB, Leite CM, Helena CV, Franci CR, Anderson GM, Hoffman GE, Anselmo-Franci JA. Kisspeptin regulates prolactin release through hypothalamic dopaminergic neurons. Endocrinology 2010;151:3247-3257. 